\title{
Purple Hibiscus: A Postcolonial Feminist Reading
}

\section{Musa W. Dube ${ }^{1}$}

\begin{abstract}
The article investigates how Purple Hibiscus utilizes intertextuality and explores the intersection of class, gender, race, postcoloniality and violence in a context of theological imagination represented by two siblings, who express their Roman Catholic faith differently. The character of Papa Eugene, whose extreme religiosity and violence pervades the book, is depicted as a colonized subject, who embodies epistemic violence of a colonial past. The decolonizing postcolonial feminist perspective of the book is best modeled by the character of Aunty Ifeoma and how she expresses her Christian faith as an African woman. Whereas, Aunty Ifeoma is an articulate intellectual, women of different status are shown to use different means of resisting patriarchy and violence in the quest for liberating relationships, thereby modeling various expressions of feminist agency. This paper, therefore, explores the intersectionality of gender, class, race, religion, postcoloniality and power in Chimamanda Ngozi Adichie's debuting novel, Purple Hibiscus set in a political context of a military coup in Nigeria.

Keywords: Chimamanda N. Adichie, James H. Cone, Colonial Violence, Decolonization, African Christianity
\end{abstract}

\section{Purple Hibiscus: A Postcolonial Feminist Reading ${ }^{2}$}

The biggest weapon wielded and actually daily unleashed by imperialism against the collective defiance [of the colonized] is the cultural bomb. The effect of a bomb is to annibilate a people's belief in their names, in their languages, in their environment, in their heritage of struggle, in their unity, in their capacities and ultimately in themselves" (Ngugi, 1986:3).

"I had to find a new way of talking about God that was accountable to black people and their fight for justice" (James Cone, 2018).

\section{Introduction}

Purple Hibiscus is Chimamanda Ngozi Adichie's debut novel published in 2003. It features two Igbo families: Papa Eugene's family, consisting of his wife Beatrice

1 University of Botswana Theology and Religious Studies dubemw@mopipi.ub.bw. She is a research fellow at Department of Religion and Classical Studies, University of South Africa.

2 This paper is written in honor, remembrance and celebration of Prof James H. Cone, the founding father of black theology, for his commitment, creativity and groundbreaking scholarly work in the area of black theology of liberation. 
Achike, commonly called Mama, a daughter named Kambili, a son named Chukwuka, but always referred through his childhood nickname, Jaja and Himself. They also have a household help, Sisi and a driver, Kevin. They live in Nnugu. Papa Eugene is a wealthy businessman, owning several factories, high value properties, and the Sunday Standard newspaper, which is the only paper that dares to give a critical voice towards the corrupt and oppressive military government of Nigeria. The second family is Aunty Ifeoma's family, consisting of two sons, namely; Obiora and Chima, one daughter Amaka and their widowed mother. Aunty Ifeoma is a lecturer at the University of Nigeria in Nsukka. She embodies critical thinking, especially towards gender and colonial ideologies. Papa Eugene and Aunty Ifeoma are siblings, children of Papa Nnukwu and are both Roman Catholic practicing families. Papa Nnukwu, their father, did not convert to Christianity, but remains a practicing believer in African Indigenous ways of belief and worship, a stance that allows the reader to judge the different types of Christianities embraced by his children, Ifeoma and Eugene - judged by their attitude towards their father. Religion is central to the plot of Purple Hibiscus, highlighting colonized hybrid minds and decolonizing hybrid minds.

Papa Eugene is an extravagant giver to the church, the poor, schools and his own immediate family. But his giving is always tied to asserting his power over his wife, children, church, village, public opinion and those he regards as pagans. Jaja, his biological son, begins to talk back, to name his violence and to be protective towards his sister and mother. However, Eugene meets his greatest resistance from his biological father, Papa Nnukwu, and his sister, Auntie Ifeoma. Papa Nnukwu, a traditionalist, holding on to the indigenous beliefs and rituals of the Igbo people, lives in a shack, wears faded clothes, eats food without meat and is sickly, but will not surrender to his rich son's use of material power to coerce him to Christian conversion. Auntie Ifeoma, a widowed single mother with four growing children, is a struggling university lecturer. She too uses a faded dining table with mismatched chairs and dinning plates, a cracking van and lives in an old congested apartment that does not have enough bedrooms for her children. Being Catholic herself, she epitomizes indigenized Christianity singing Igbo hymns, attending masquerade festivals, visiting their father's supposedly pagan compound and taking her children to spend time with him. Although she is struggling, her intellectual class allows her to resist her brother's use of material power to force his version of Catholicism upon his dependents and public pressure to remarry.

Kambili, a 15-year-old daughter of Papa Eugene is the narrator of their stories. The narrative setting of Purple Hibiscus is in the recent military coup, which leads to escalated violence against critical citizens, lack of petrol, water, electricity and money to pay workers their salaries - a context that leads to multiple public 
strikes amongst medical personnel, students, lectures and many other professionals, bringing most services to a standstill and hiking prices of food and the available services. It also leads to migration to other countries, as the conditions of living and survival become harder. Phillipa, a friend of Aunty Ifeoma and University lecturer is reported to have relocated to the U.S., where she has become adjunct professor, sharing a cramped office but insisting that, "at least teachers are paid there" (p76). At the end of the novel, Aunty Ifeoma and her children have relocated to the U.S., where she takes a job as a lecturer. This political context constitutes postindependence disappointments (Anderson, 1991).

\section{Religious Setting and Its Political Overtones}

While the military coup is the national setting of the story, Purple Hibiscus is narrated within a religious timeframe stated in three stages; namely; Palm Sunday, Before Palm Sunday and after Palm Sunday. These three settings divide the novel into three parts. Biblically, Palm Sunday is Christian holiday that occurs a Sunday before the Easter Holiday, or Holy week. It commemorates the triumphal arrival of Jesus in Jerusalem, riding a colt, being hailed Son of David, and palm leaves being laid down for his colt by the crowds. Matthew 21:1-11, describes the event that becomes celebrated as Palm Sunday as follows:

As they approached Jerusalem and came to Bethphage on the Mount of Olives, Jesus sent two disciples, saying to them, "Go to the village ahead of you, and at once you will find a donkey tied there, with her colt by her. Untie them and bring them to me. If anyone says anything to you, say that the Lord needs them, and he will send them right away." This took place to fulfill what was spoken through the prophet: "Say to Daughter Zion, 'See, your king comes to you, gentle and riding on a donkey, and on a colt, the foal of a donkey." " The disciples went and did as Jesus had instructed them. They brought the donkey and the colt and placed their cloaks on them for Jesus to sit on. A very large crowd spread their cloaks on the road, while others cut branches from the trees and spread them on the road. The crowds that went ahead of him and those that followed shouted, "Hosanna to the Son of David!" "Blessed is he who comes in the name of the Lord!" "Hosanna in the highest heaven!" When Jesus entered Jerusalem, the whole city was stirred and asked, "Who is this?" The crowds answered, "This is Jesus, the prophet from Nazareth in Galilee."

Jesus entering Jerusalem, being characterized as King and hailed as "Son of David by the crowds, who treated him as royalty, laying palms and their cloaks for his colt to ride, was a subversive political entry that challenged the Roman Empire and the collaborative Sadducees, who dwelt in Jerusalem. Having experienced a long line of colonial domination, beginning with the Babylonian exile to the Roman Empire of Jesus' time, the Jews had developed a narrative of hope and resistance that 
held that God would send them a messiah, who would liberate them from colonial powers (Grau, 2004:78-98). The Messiah was to come from the house of David. For Jesus to arrive in Jerusalem, being hailed Son of David and king was a direct challenge to the Roman Empire and the collaborating religious leaders. Governor Pontius Pilate, who was assisted by a battalion of soldiers to ensure that the colonized Jews in Palestine remained faithful to the Empire, lived in Jerusalem when the defiant Jesus arrived being hailed the long expected political messiah.

In addition to evoking messianic hope of liberation from colonial powers, Jesus had come to Jerusalem to celebrate the Passover. The latter recalls God's act of setting the Israelites free from their enslavement in Egypt (Cone, 1997). The tradition of Palm Sunday thus reeks with liberation undertones--suggesting freedom from enslavement and colonizing structural powers and insisting on liberation. of course, Jesus' subversive entry did not escape the powers that be. He was arrested and tried by Pontius Pilate and was found guilty for challenging the powers of Caesar, the Roman Emperor. He was accordingly sentenced to death by hanging on the cross, which was the Roman imperial style of eliminating those who challenged their powers. Yet He resurrected from the death, thereby signaling continual resistance against oppressive powers.

For Purple Hibiscus to evoke Palm Sunday, by utilizing it as the opening setting of the narrative is to underline the arrival of another king, who will challenge the colonial and oppressive powers and religious leaders. Who is the daring king of liberation and who is the embodiment of oppression? What prize shall he pay for staging liberation through direct affront to the oppressive power? The novel opening line states, "Things began to fall apart at home when my brother, Jaja, did not go to communion and Papa flung his heavy missal across the room and broke the figurines on the étagère" (2003:3). The narrator, Kambili, continues to tell us that "When Papa did not see Jaja go to the altar that Palm Sunday that's when everything changed, he banged his leather bound missal, with the red and green ribbons peeking out, down on the dining table when we got home... Jaja you did not go to communion," (6) Papa said in assertive askance. Although not explicitly stated, I suppose that this leather bound missal with ribbons is the Bible. The narrator tells us that, Jaja stared at the missal on the table as though he were addressing it and said. "The wafer gives me bad breath.... And the priest keeps touching my mouth and nauseates me" (7). Nausea is the feeling that one gets when the body wants to throw out that which one has eaten, supposedly rejecting that which one has swallowed. It is a revolt. To find the priest's touch, during the Lord's Supper, nauseating is to reject a major religious symbol, its officiants and all that they stand for. By referring to the bread of the Lord's Supper as a wafer was a major statement of resistance to Papa Eugene, who as Kambili, the narrator tells us, "insisted we call it the host 
because "host" came close to capturing the essence, the sacredness, of the body of Christ" (7). Indeed Papa Eugene hastens to correct Jaja asserting, "It is the body of our Lord. You cannot stop receiving the body of our Lord. It is death, you know that" (7). But Jaja has resolved to challenge his violent and over religious father, and his accommodating Priests, by rejecting that which he holds most sacred. He responds, "Then I will die" and to underline, he repeats, "Then I will die Papa," (7) than eat the wafer or have the priest touch me. This is nausea, the revolt. The die of resistance is cast. During lunch Jaja refuses to give his compliments to a newly produced drink from his father's factory. He leaves the dining table while others are still eating and does not come for dinner that evening, thereby, breaking the stringent rules of his father. As the narrator underlines, "This had never happened in my entire life. Never" (14). Given their father's obsessive control and violence over their lives Kambili the narrator thought their "compound walls would crumble... and the sky would cave in" (14) due to Jaja's rebellion, his courage to speak back to Papa Eugene. Jaja was breaking the silence. In shock, Kambili lies down with high temperature, stating that:

I let my mind rake through the past, through the years when Jaja and Mama and I spoke more with our spirits than our lips. Until Nsukka. Nsukka started it all; Aunty Ifeoma's little garden next to the veranda of her flat in Nsukka began to lift the silence. Jaja defiance seemed to me now like Aunty Ifeoma's experimental purple hibiscus; fragrant with the undertones of freedom, a different kind of freedom.... A freedom to be, to do (16).

Jaja was thus making a triumphant entry as a subject that challenges oppression as represented by Papa Eugene and his accommodating church leaders, who pretended they did not see his violence upon his family, given the massive material support he gave to the church and its institutions. The narrative informs us that Jaja was a name of stubborn and defiant king, who ruled during the colonial times. Aunty Ifeoma says, "I told your mother that it was an appropriate nickname that you would take after Jaja of Opodo. He was the king of the Opodo... and when the British came, he refused to let them control trade. He did not sell his soul for gunpowder like the other kings, so the British exiled him to the West Indies" (145). ${ }^{3}$

In addition to starting off the novel by evoking the Palm Sunday and its undertones of resisting the Empire, Purple Hibiscus also evokes another text and story,

3 Ironically, Father Benedict, the Catholic Priest, who benefits most from Papa Eugene's generosity and who gets silenced from criticizing his violence towards his wife, sees Eugene as the rebellious king through his Sunday Standard Newspaper that is critical towards the oppressive government, Purple Hibiscus, 2003, 4-5. 
namely; Chinua Achebe's Things Fall Apart." As noted above, its opening sentence says "Things began to fall apart at home when my brother, Jaja, did not go to communion and Papa flung his heavy missal across the room and broke the figurines on the étagère" (2003:3). Published in 1959, Things Fall Apart is a novel featuring Okonkwo and presented in three parts; namely; first, his personal history and the customs and beliefs of the Igbo; while the second and third parts introduce the influence of British colonialism and Christian missionaries on Igbo people. Achebe explored the cultural conflict in the encounter of Christian Doctrine and Igbo traditions (Katongole, 2011:125-134). Purple Hibiscus is set in the postcolonial Nigeria of a military coup, and, it too explores the cultural conflict between Christian Catholic traditions and Igbo traditions, especially as embodied by Papa Eugene and his attitude to all those who believe otherwise, especially his father, Papa Nnukwu, who insists following the path of African Indigenous Religions ways of worship.

Postcolonial Feminist Framework

With this background, the paper seeks to carry out a postcolonial feminist reading of Purple Hibiscus (Dube, 2000; Donaldson, 1992). As used here, postcolonial framework does not denote a linear approach to history or theory. It refers, rather, to the spiral of cultural histories, economic structures and political systems that continue to overlap in time and space of continents and countries ever since modern colonial contact zones (Pratt 1992; Said 1993; Boehmer 1995). Postcolonial feminist framework, as used here, seeks to analyze how the history of colonial contact zones continues to be lived out in the narrative of Purple Hibiscus, paying attention to voices of resistance, collaboration and mimicry to the forces of colonialism and its legacies as well as assessing the its intersectionality of race, gender and class (Bhabha, 1994; Nicholls, 2010). As used here, colonialism, therefore, does not only refer to the domination of the land or the occupying of the physical or geographical space of the other by dominating super powers and their allies. It also refers to the occupation of the cultural, spiritual and psychological space of the Other, which outlives the historical even (Ngugi, 1986; Cesaire, 2000).

In his book Decolonising the Mind, Ngugi has described the effect of colonialism as a cultural bomb, which teaches its survivors to hate themselves and their cultures, admiring rather that of their colonizers. He holds that "the effect of a bomb is to annihilate a people's belief in their names, in their languages, in their environment, in their heritage of struggle, in their unity, in their capacities and ultimately in themselves" (1986:3). While Ngugi uses the term, "cultural bomb", epistemic violence is "a term coined by postcolonial feminist Gayatri Spivak Chakravorty to refer to the destruction of indigenous languages, culture and thought that accompanies colonial conquest" (Spivak, 1999; Buchanan, 2010:446-5). In Purple Hibiscus the character of Papa Eugene embodies epistemic violence. He has swallowed the 
cultural bomb, and has been shattered into a thousand pieces. He is the product of colonial violence, thereby unable to know himself. The Postcolonial framework used here thus assesses the memories and the embodiment of resistance, collaboration and mimicry to the historical colonial experience as attested by the characters of Purple Hibiscus.

Aunty Ifeoma is the antagonist to Papa Eugene's values. She is not only a female, middle-class intellectual; she also resists both patriarchy and colonialism. The book's feminist stance is also articulated by other, supposedly submissive, characters such as Kambili, Mama Beatrice and Sisi, who slowly rise up to resist Papa Eugene's violence in the most subtle and unexpected ways. Amaka, Aunty Ifeoma's daughter, on the other hand, seems to be the embodiment of something new to come- a higher level of postcolonial feminist liberation than that of her mother. Among other indicators, part her radicalism is highlighted by her refusal to undergo baptism, if the requirement to take a baptismal name, that is either Western or biblical still applies. Her mother and Father Amadi are of the opinion that she can take the name and then ignore it thereafter, but she wants the whole tradition scrapped. By undertaking to do a postcolonial feminist reading of Purple Hibiscus, this paper seeks to analyze the intersection of gender, class, postcoloniality and the imagination of liberation theology. First, I want to make the case that Papa Eugene is presented as the embodiment of colonial and patriarchal legacies and go on to highlight how Aunty Ifeoma stands at the resisting end (Aschroft, et. al. 2002).

\section{Papa Eugene is "Too Much of a Colonial Product"}

Indeed Purple Hibiscus' Palm Sunday opening does not beat around the bush concerning Papa Eugene's identity as a colonized mind. Describing Papa Eugene's confrontation with Jaja's refusal to give any comment on the newly produced drink from Papa's factory, Kambili, the narrator, says;

Jaja have you not shared a drink with us, gbo? Have you no words in your mouth? He asked entirely in Igbo. A bad sign. He hardly spoke Igbo, and although Jaja and I spoke it with Mama at home, he did not like us to speak it in public. We had to sound civilized in public, he told us we had to speak English. Papa's sister, Aunty Ifeoma said once that Papa was too much of a colonial product. She had said this about Papa in a mild, forgiving way, as if it were not Papa's fault, as one would talk about a person who was shouting gibberish from a severe case of malaria (2003:13). (Emphasis mine).

Papa Eugene embodies colonial epistemic violence, so much so that he is likened to a person "shouting gibberish from a severe case of malaria." Of course malaria 
develops after one is beaten by an infected mosquito that releases parasites into ones' blood. The parasites multiply and become life threatening. Malaria parasites thus colonize the body as they grow in one's blood. Papa Eugene is described as one who has been beaten by a colonial mosquito, whose parasites continue to wreak havoc on his system. His embodiment of the colonial cultural bomb as the embodiment of death is perhaps best established by the old man Anikwenwa, who upon hearing that Papa Eugene had arrived in the village decided to go and greet him. But when he arrived, Papa Eugene started screaming, "What is Anikwenwa doing in my house? What is a worshiper of idols doing in my house? Leave my house" (70). As two men drag Anikwenwa out of the compound, he threw words at Papa Eugene saying, "Ifukwa gi. You are like a fly, blindly following a corpse into the grave" (70). This simile presents Papa Eugene as a tragic colonized figure, who is to be pitted for his insistence on venerating the colonial ideologies. He is without sight. His choices for life are ironic, for they don't lead to life, but death, to the colonial grave.

Papa Eugene is thus a noted victim of the colonial cultural bomb. The multiplication of the colonial parasite in his system makes him pitiful. He refuses to sing Igbo hymns in church; he does he appreciate a sermon in his own language, and "did not like to make his confession in Igbo" (104). When he finally speaks Igbo it is supposedly, "a bad sign!" The narrator at several points informs the reader when Papa Eugene speaks Igbo, because it is always a notable moment, calling attention to something bad. For example, when he finds Mama and Jaja allowing Kambili to eat a bowl of cereal 10 minutes before the Eucharist, instead of observing the imposed fast, he asks them in Igbo, "Has the devil asked you all to go on errands for him?... Has the devil built a tent in my house"? (102 \& 69, 97, 77). These questions culminate with Papa taking off his belt and hitting the three of them. As stated above, he associated speaking English with civilization. Hence at the village the reader is informed that, "Papa liked it when the villagers made an effort to speak English around him. He said it showed good sense" (60). Papa also "Changed his accent when he spoke, sounding British, when he was with the white religious groups such as Father Benedict and Sister Margaret” (46). Papa Eugene's preference for English language might be the reason that, while the rest of his family use their native Igbo names, he and his wife use English/Baptism names-Eugene and Beatrice. Indeed, the very fact that he prefers language of worship and liturgy to be English, suggests that in his perception, God must be white and English might be a heavenly language.

Since language is not just a medium of communication, but an articulation of whole culture as well as a construction of the same (Fanon, 1967; Ngugi, 1986), it goes without saying that Papa Eugene's marginalization of Igbo language will go together with the dismissal of the whole Igbo culture and traditions. This aspect is best 
portrayed through his stringent religious ways that regard non-Christians as pagans and other Catholics as less pious for their accommodation of Igbo songs and change of liturgy from cold continuous prayers to celebratory interceptions with various songs, during the process of worship. As his interaction with Anikwenwa attests, Papa Eugene rejected his own biological father, Papa Nnukwu, for insisting on worshiping his Chi, God, in the traditional way. He hardly supported him — giving him a very thin bunch of notes--thinner than the ones he gives to his gateman and driver. At some point he denied his biological father the right to see Jaja and Kambili, until elders were called to intervene. Papa Nnukwu lived in poor house and ate food without meat and wore worn clothes, but Eugene would not support him because of his pagan ways. His biological father is not allowed to come to his house, and Jaja and Kambili are only allowed to see him for 15 minutes under strict rules not to eat or drink anything at his household. Kambili and Jaja once exceeded with five minutes and they were taken for confession. In his house, Papa Eugene hangs the picture of his father-in-law for he was a celebrated missionary, who had converted to Christianity. When Papa Nnukwu passes on, Eugene does not attend his funeral, although Aunty Ifeoma asks him to sponsor the funeral. His Christian practice is an anxious exercise in making a complete break with the past (Meyer, 2004:447-476).

The contest over Papa Nnukwu's belief system and how Papa Eugene interprets it, is perhaps the height of the conflict in Purple Hibiscus. For many years Aunty Ifeoma and Papa Eugene did not talk or visit each other due to his view of their father' faith. While he called him a pagan, Aunty Ifeoma calls him a traditionalist, who happens to worship God in a different way. Jaja and Kambili were severely punished with boiling hot water poured over their feet for having slept and stayed in the same house with their grandfather during their visit to Aunty Ifeoma in Nssuka. Papa Eugene thus exhibits an extremely colonized mind that relegates African belief system to the realm of evil.

The final countdown was the gift of painting of Papa Nnukwu, which Amaka gave to Kambili. She brought the painting home, into Papa Eugene's house. While Kambili and Jaja were sitting, engrossed watching the painting, their father comes in and goes into a violent frenzy, kicking Kambili endlessly with his heavy boots until she was numb and got hospitalized for many days. Papa Eugene's religious piousness seems completely unable to deter him from violence. His attack on the state for its violence and corruption seems unable to stop him from violence on his own family. His wife miscarriages twice due to his violence, but these are the publicly acknowledged ones. One of Jaja's fingers were now crippled because, after failing to top the catechism class, his father beat him severely, breaking his finger. Papa Nnukwu insists that his son, Eugene, was mentally destroyed by missionary theology. He problematizes the trinity that intimates that Jesus is equal to the Father. With 
such a teaching, he insists Eugene could only disrespect his own biological father. Papa Eugene is generally depicted as a severely violated and violent product of colonialism, since for him to live is to deny himself and his culture-a posture that makes him self-alienated from his humanity and turns him into wounded animal.

\section{Aunty Ifeoma: The Freedom Gardner}

Turning to Aunty Ifeoma, her place is where the purple hibiscus, associated with freedom, grows. Her home is a place where Jaja and Kambili would pluck its stocks and take them back to Enugu, like priced diamonds, to plant them in their garden. Papa Eugene, unsuspicious of these symbolic goods of freedom, safely stored them in his fridge, awaiting summer to be planted. Unknown to him, the winds of change had come upon his house, blowing from Aunty Ifeoma's place. The novel makes no secret about it as the narrator tells us "Nssuka started it all; Aunty Ifeoma's little garden next to the verandah of her flat in Nssuka began to lift the silence" (2003: 16). Silence is more often than not a sign of oppression, for the subjugated are denied the right to speak and to be heard (Dube, 2016:54-72; Dube, 2016:144-154). Kambili, Jaja and Mama Beatrice were silenced by Papa Eugene and his imposed religious practice; his wounded self that unleashed violence upon them and employed material power to silence even potential voices of decent, namely; the Priests and the church. Religious leaders surely knew about the terror that Papa Eugene worked upon his family, for each time after beating and injuring his kids and wife, he would run out weeping as he took them to the Catholic hospital, claiming that an accident happened. Kambili, who was severely kicked for her grandfather's painting, is notably tendered by a white sister back to health, thus indicating the church's compliance in the covenant of violence (Maluleke \& Nadar, 2002:5-17). However, as reported, Papa Eugene single handedly supported St. Agnes, its hospital and always signed a big check for the Daughters of Immaculate Heart Secondary school (2003:4-6). Nowhere do we ever find a priest counselling him about his violence as an evil-founded practice. Aunty Ifeoma nails the function of his giving, pointing out that, "the members of Umunna, in fact everybody in Abba, will tell Eugene only what he wants to hear. Do our people not have any sense? Will you pinch the finger that feeds you?" (96). However, Aunty Ifeoma, like her Daddy, Papa Nnukwu, refuses to be bought out by her rich relative. As she reminds Mama Beatrice;

Have you forgotten that Eugene offered to buy me a car, even before Ifediora, my husband, died? But first he wanted us to join the Knights of St John. He wanted us to send Amaka to a convent school. He even wanted me to stop wearing make-up! I want a new car, mwunye $m$, and I want to use my gas cooker again and I want a new freezer and I want money so that I will not have to unravel the seams of 
Chima's trousers when he outgrows them. But I will not ask my brother to bend over so that I can lick his buttocks to get these things (95).

Similarly, Papa Nnukwu was offered all good things, as long as he converted to Christianity, and he too declined, preferring to remain with his freedom than to be bought out. For years, Aunty Ifeoma did not talk to her brother, for refusing to let their father come into his house due to his indigenous religious beliefs, but then she decided that this too was Papa Eugene's way of silencing her and marginalizing Jaja, Kambili and Mama Beatrice from any other dissenting voices. She returns to talking to Papa Eugene and to visiting his house bringing her own kids. She insists on Jaja and Kambili visiting her and spending time with their cousins. In so doing, she exposes them to another view of parenting; another view of Catholicism, another view of African Indigenous belief system, another view of life. She takes them out to see the masquerade, she teaches them that Papa Nnukwu is not a pagan, as Eugene has taught them, but rather that he is a traditionalist, who worships the same God, but in a different method. It is to Nssuka that their grandfather comes for medical attention and they get to live under the same roof with him for days, instead of the 15 minutes visit imposed on them. They also get to have an opportunity to listen to him praying in his African way of worshipping. In Nssuka, in Aunty Ifeoma's house, they discover that Catholic order of prayers can be said in Igbo and they can be punctuated with many Igbo songs. Jaja and Kambili discover, in Nssuka, that there is another way of parenting - where children are not silenced but are allowed to think and speak freely, while their parent acts more like a coach. It is to Nssuka that the violated Mama Beatrice runs- there she is informed to leave the burning house of violence before it carves in on her.

Nssuka, as represented by Aunty Ifeoma's house and beliefs, is a decolonizing feminist space of liberation (Mills, 1994; Dube, 2001:100-120). And so Kambili and Jaja return to their home carrying stocks of purple hibiscus to plant it in their garden. Although Papa Eugene meets them with purgatory acts, scalding their feet in the bath with boiling water, for sleeping under the same roof with their pagan grandfather without telling him; although he takes them to the priest to confess having watched the heathen masquerade festival and although he kicks Kambili to almost death for bringing a painting of their grandfather into his house---it is too late. Purple hibiscus is growing in his garden, planted by Jaja from Aunty Ifeoma's garden.

Aunty Ifeoma is not only a decolonizing figure, she is also depatriarchalizing figure. This is clearly stated by her attitude to her widowhood status. When she received questions about her widowhood, she stated that, "sometimes life begins when marriage ends" thereby underlining that woman need not see their lives as 
non-existent outside marriage (Adichie, 2014). Similarly, when her father mentions that he is praying for her to find another husband, she asks him to pray rather, that her application to the position of senior lecturer should succeed. Ifeoma speaks critically to Mama Beatrice concerning childbearing and violence in her marriage. Mama Beatrice is worried that she has given birth to only two kids to Eugene and that his community will feel that it is inadequate and might try to find another wife for him. Aunty Ifeoma dissuades her from measuring her worth by the number of children she has borne for her husband. Concerning Eugene's violence, she informs Beatrice that when the house is on fire one must run out before the roof falls in, trapping the victim.

Beatrice's attempt to leave is aborted, since she seemingly chooses to return to her home. Nonetheless, Mama Beatrice begins to slowly poison Papa Eugene to death after a violent incident which led to the death of her unborn child. Mama Beatrice was assisted by Sisi, their housekeeper, to find the poison that would finally eliminate Eugene. Indeed Kambili, who was the most obedient and in a terrified awe of her father, also began to show acts of resistance. First, she fell in love with Father Amadi, a Roman Catholic Priest who called himself with his Igbo name, preached in Igbo and sang Igbo hymns- thereby representing everything that Kambili's father detested. Second, Kambili refused to hand the painting of her grandfather to her father and ended up being severely kicked. Purple Hibiscus thus indicates various forms of resistance to patriarchy by women of different status. While Aunty Ifeoma is an openly articulate and fearless intellectual, one begins to realize that women such as Mama Beatrice, Kambili and Sisi also had different ways of resisting. Indeed, Kambili, being the narrator of the whole book, is no longer silenced. She has found her voice and names the oppression that occurred in her family and how they found their way to freedom. In so doing, Purple Hibiscus models various forms of feminist agency (Avishai, 2016:261-271; Gammage, et. al., 2016:1-9).

\section{Conclusion}

In Purple Hibiscus, Papa Eugene is the embodiment of the colonial legacy and its violence, while Aunty Ifeoma family is a hybrid postcolonial subject that problematizes both the colonial and patriarchal legacies, seeking to create spaces and relationships of freedom-freedom that empowers people to be, to do, as the narrator tells us. Hence the defiance of Jaja and indeed of Kambili and their mother, is associated with Aunty Ifeoma's garden with its rare purple hibiscus flowers that began the process of breaking the silence and opening the space for those under the oppressive rule of Papa Eugene to assert themselves, insisting on their right to human dignity - the right to speak and to be heard, the right to worship in their African language; the right to associate with those who believe differently. It is the right to 
have the "freedom to be". Just as the book begins with resistance to Papa Eugene, exampled by Jaja, this resistance grew to include Kambili, who begins to assert her right to own the painting of her grandfather, regardless of what Papa Eugene thinks of their grandfather. Mama Beatrice, who has borne many violent thuds behind the closed doors of their bedroom and who had many other miscarriages, before the last two that are publicly pronounced as accidents, also begins to catch the scent of freedom, of the purple hibiscus, growing in her own garden. She had spent many years endlessly polishing the ballet figurines in the étagère to cope with violence in her house, on her body, on her children-including the unborn ones. His violent embodiment of the colonized mind was bad news for her current children and for the unborn children. He kills even the unborn children, thus underlining that colonized patriarchal figures are bad news for our common futures.

As the narrative comes to a closure, Papa Eugene is dead. He has been poisoned by his wife, with the assistance of Sisi, their house help. Jaja claims the responsibility for poisoning his father and goes to prison. The public blames the government for his death, given his critical newspaper. Mama Beatrice continues to publicly say she poisoned him, but no-one believes her. Rightly, so! Papa Eugene could have been killed by anyone. Perhaps, as the old man Anikwenwa asserts and warns Papa Eugene was; "like a fly blindly following a corpse into the grave" (2003:70). He was buried in the grave of colonial violence, which stopped him from believing in his name and language. He died when he got bitten by the colonizing mosquito with its deadly parasites, which kept multiplying in his blood until he was gibberish. He, therefore, was a violent product of the colonialism's epistemic violence. But Aunty Ifeoma's purple hibiscus offers a balm of healing in Nssuka. Now the reader realizes that when Jaja triumphantly burst into the Palm Sunday space, defiantly riding the kingly colt of liberation, there were many crowds laying Palm leaves and their cloaks for him to enter Jerusalem - to shake it up and to demand decolonization and human dignity. Perhaps these are the rare petals of the Purple Hibiscus, the look of freedom from colonial and patriarchal oppression.

\section{References}

Adichie, C.N. (2014). We Should All be Feminists. London: 4th Estate.

Adichie, C.N. (2003). Purple Hibiscus: A Novel. London: 4th Estate.

Anderson, B. (1991). Imagined Communities: Reflections on the Origin and Spread of Nationalism. New York: Veso.

Ashcroft, B., Griffiths, G.,and Tiffin, H. (2002). The Empire Writes Back: Theory and Practice in Postcolonial Literatures. New York: Routledge.

Avishai, 0. 2016. Theorizing Gender from Religion Cases: Agency, Feminist Activism and Masculinity. Sociology of Religion: A Quarterly Review, 77(3), 261-271. 
Bhabha, H. (1994). The Location of Culture. New York: Routledge.

Boehmer, E. (1995). Colonial and Postcolonial Literature. New York: Oxford University Press.

Buchanan, I. (2000). Oxford Dictionary of Critical Theory. Oxford: Oxford University Press. Cesaire, A. (2000). Discourse on Colonialism. New York: Monthly Review.

Cone, J.H. (2018). Said I Wasn't Gonna Tell Nobody: The Making of a Black Theologian. Maryknoll: Orbis Press.

Cone, J.H. (1997). God of the Oppressed. New York: Orbis Press.

Donaldson, L. (1992). Decolonizing Feminisms: Race, Gender and Empire. Chapel Hill: University of North Carolina Press.

Dube, M.W. (2016). "Gender in African Christianity." In Isabel A. Phiri (ed), Anthology of African Christianity." Geneva: WCC, 144-154.

Dube, M.W. (2016). "The Subaltern Can Speak: Reading the Mmutle (Hare) Way.", InJournal of Africana Religions, 4(1), 54-72.

Dube, M.W. (2017). "Dinah (Genesis 34) at the Contact Zone: Shall our Sister Become a Whore?", In Juliana Claassen's \& Carolyn Sharp, eds. Feminist Frameworks. London: T\&T Clark, 39-57.

Dube, M.W. (2001). "Postcoloniality Feminist Spaces and Religion.” In Donaldson \& Kwok Pui Lan, eds. Postcolonialism \& Feminism Religion. New York: Routledge, 100-120.

Dube, M.W. (2000). Postcolonial Feminist Interpretation of the Bible. St. Louis, Missouri: Chalice Press.

Fanon, F. (1967). Black Skin White Masks. New York: Grove Press.

Gammage, S., Naila K. and Van der Meulen Rodgers, Y. (2016). "Voice and Agency: Where Are We Now?", In Feminist Economics, 22(1), 1-9.

Grau, M. (2004). "A Postcolonial Christology for Times of Neocolonial Empire", In Postcolonial Theologies: Divinity and Empire, ed. Catherine Keller, Michael Nausner and Mayra Rivera. St. Louis: Chalice Press, 78-98.

Katongole, E. (2011). The Sacrifice of Africa: A Political Theology for Africa. Grand Rapids: Eerdmans.

Maluleke, T.S. and Sarojini, N. (2002). "Breaking the Covenant of Violence Against Women," Journal of Theology for Southern Africa, 114, 5-17.

Meyer, B. (2004). Christianity in Africa: From African Independent to Pentecostal-Charismatic Churches. Annual Review of Anthropology, 33,447-474.

Mills, S. (1994). Writing Women and Space: Colonial and Postcolonial Geographies. New York: Guilford Press.

Nicholls, B. (2010). Ngugi wa Thiong'o: Gender and the Ethics of Postcolonial Reading. Surrey: Ashgate Publishing Limited.

Pratt, M.L. (1992). Imperial Eyes: Travel Writing and Transculturation. New York: Routledge.

Wa Thiong'o, N. (1986). Decolonizing the Mind: The Politics of Language in African Literature. Oxford: Heinemann \& James Curry.

Said, E. (1993). Culture and Imperialism. London: Chatto and Windows.

Spivak, G. (1999). A Critique of Postcolonial Reason. London; Cambridge: Harvard University Press. 